\title{
Material Flow Analysis of Nitrogen in Maeklong River Basin in Ratchaburi and Samut Songkhram Province, Thailand
}

\author{
Chanathip Pharino $^{1} \cdot$ Nop Sailamai $^{1} \cdot$ Pinida Leelapanang Kamphaengthong $^{2}$
}

Received: 16 September 2015 /Revised: 10 July 2016 / Accepted: 5 August 2016 / Published online: 2 September 2016

(C) Springer Science+Business Media Singapore 2016

\begin{abstract}
Eutrophication in the Gulf of Thailand can trigger serious ecological and economic impacts of Thailand. Maeklong River, one of the five major rivers flowing into the Gulf, carries nutrients into the Gulf of Thailand and causes eutrophication. This study aims to determine sources and amounts of nitrogen from man-made activities in Ratchaburi and Samut Songkhram Provinces where Maeklong river basin is located. The study applied mass flow concept to analyze nitrogen and its contribution ratio from anthropogenic activity, and recommended strategies to solve eutrophication problem in the Maeklong River. The scope of nitrogen flow analysis is classified into four main activities including agriculture (rice cultivation, livestock, and aquaculture), industry, households, waste management, and wastewater treatment. The results indicated that total nitrogen release into the river in 2010 is $25,911 \mathrm{tN}$. Livestock farming is the major activity discharging nitrogen into the river which accounted for $55 \%(14,241 \mathrm{tN})$ of the total discharge nitrogen. Industry and household are the second and the third highest contributors of $\mathrm{N}$ stock into the river, respectively. Other activities have less significant contribution of discharging nitrogen into the river. To reduce $\mathrm{N}$ in the river, it is recommended increase efficiency and coverage areas of wastewater collection system and apply best practice technology to help reducing nitrogen discharge. Increase efficiency of water usages and water conservation in all activities
\end{abstract}

Chanathip Pharino

chanathip.p@chula.ac.th

1 Department of Environmental Engineering, Chulalongkorn University, Bangkok 10330, Thailand

2 Pollution Control Department, Ministry of Natural Resource and Environment, Bangkok, Thailand can help reduce pollution at source and mitigate impacts from eutrophication.

Keywords Material flow analysis · Nitrogen ·

Eutrophication · Maeklong River · Thailand

\section{Introduction}

The Gulf of Thailand is one of the major areas in Thailand that has significant activities on both tourism and fishery. The Gulf often experiences water pollution problem particularly eutrophication. In the upper Gulf of Thailand, there are five main rivers: Chao Phraya, Bangprakong, Tha Chin, Phetchaburi, and Maeklong River (Fig. 1). Areas along the five rivers are densely populated with various human activities such as rice cultivation, livestock, household, and industrial activity. The rivers receive pollutants from human activities and eventually carry pollution loadings into the Gulf.

Eutrophication in the Gulf of Thailand, according to a report from the Department of Marine and Coastal Resources, occurred 19 times in 2008 and 15 times in 2009 [1]. The recent eutrophication in 2012 at the estuary of the River killed fishes and mollusks, and caused significant economic impacts on Thai fishermen [2]. Eutrophication problem affects water quality and wellbeing of aquatics in the Gulf. Each river has varying economic activities which contribute different pollution loadings into the Gulf. If sources that discharge nutrient into the Gulf can be identified, this will help develop strategy to reduce the pollution more effectively. For instance, reduction of water pollution from key sectors and sources can be developed as one of the most effective approach to mitigate pollution impact. Effective uses of water and water conservation from key sectors can significantly contribute to solve pollution problem in the Gulf of Thailand. 


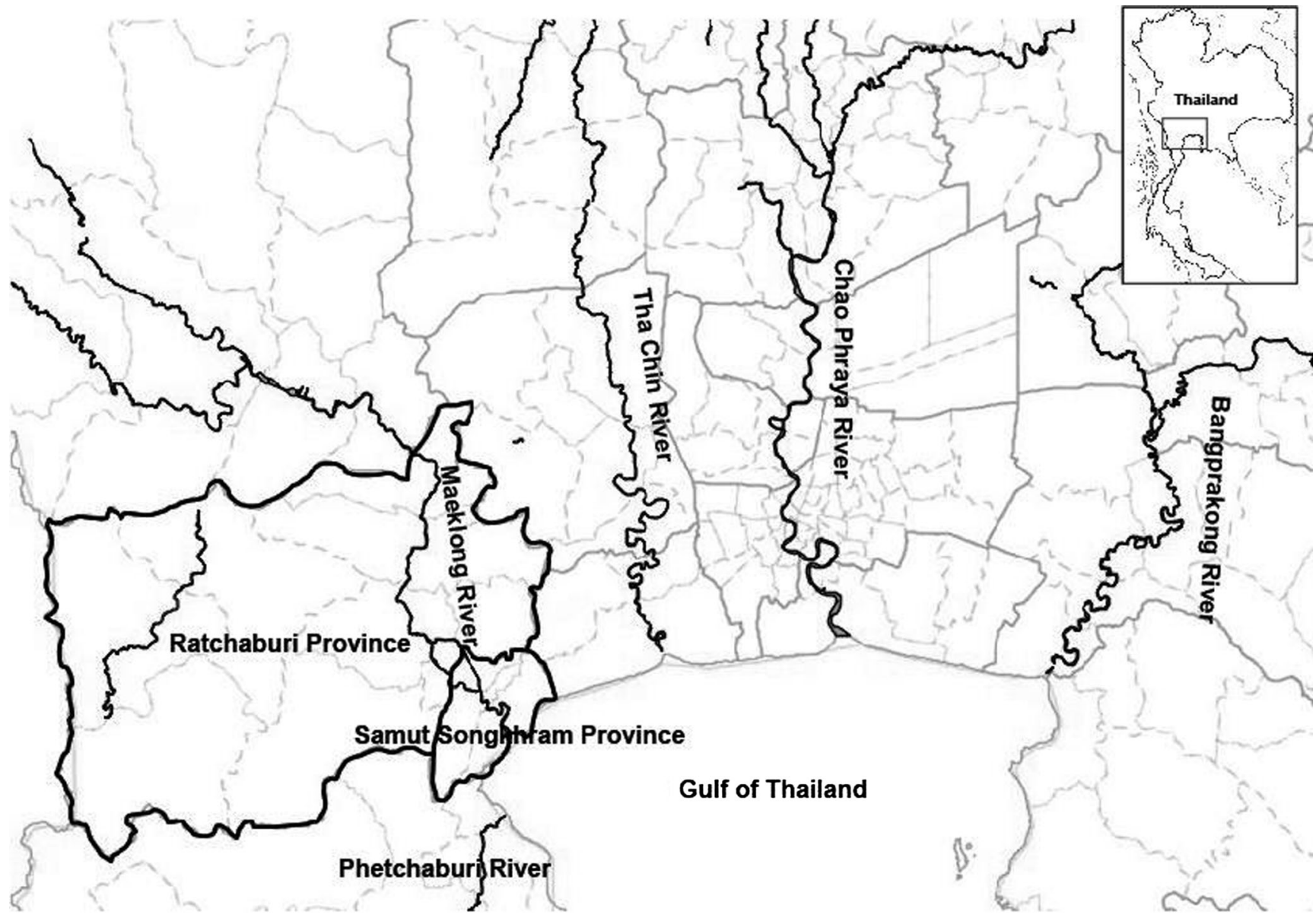

Fig. 1 Major Rivers in the Gulf of Thailand and Maeklong River flowing through Ratchaburi and Samut Songkhram Province [3]

Currently, a study of nitrogen flow into the Gulf of Thailand has been done for the Chao Praya River and Tha Chin River [4, 5]. Information about nitrogen balance in Maeklong River has still been very limited. The study aims to (1) analyze sources and amounts of nitrogen from agricultural, industrial, household, waste and wastewater management sectors in the Maeklong river basin (Ratchaburi and Samut Songkhram provinces), (2) develop nitrogen flow diagram from various sources and analyze contribution ratio of each activity to identify major causes of pollution problem, and (3) recommend strategies for environmental policy makers to solve eutrophication problem in the upper Gulf of Thailand. The research uses material flow analysis as a framework to develop $\mathrm{N}$ balance in Maeklong River to have a better understanding about the situation and identify alternatives to solve the problem [6]. This research focuses on nitrogen discharges from major anthropogenic sources located in the river basin. Finally, the study aims to have a better understanding about the major contributors of $\mathrm{N}$ discharges into the Maeklong River and suggestion to help reduce the impact of eutrophication in the future.

\section{Methodology}

\section{Study Area}

Maeklong river is one of the major rivers in the western part of Thailand. The river begins at the confluence of KwaeYai and KwaeNoi rivers and flow through Wachiralongkorn dam in Karnchanaburi province. The river flows through Ratchaburi and Samut Songkhram provinces into the Gulf of Thailand. The length of the river is approximately $140 \mathrm{~km}$. This study analyzes nitrogen flow in the Ratchaburi and Samut Songkhram provinces. These provinces cover $97 \mathrm{~km}$ of the river length, with an area of approximately $5613 \mathrm{~km}^{2}$ (forest cover $32 \%$ and agriculture area cover $50 \%$ ). Population in the Maeklong river basin is approximately 1,129,957 habitants. Major economic activities are agriculture (rice cultivation, livestock, and aquaculture) and industry. Livestock crops in the basin are pig, hen, broiler, duck, cow, and cattle. Livestock farmers in this basin produce the largest total amounts of pigs in Thailand and produce poultry more than 21 million unit per year [7]. Aquaculture crops in the basin are vannamei shrimp (semi-intensive and intensive), freshwater shrimp, tilapia, snakeskin gourami, and white perch. Major industry includes 
agro-industrial particularly food processes such as pineapplecan industry, fish sauce industry, cassava related industry, and industrial wastewater treatment (treat wastewater output from industry).

\section{Framework and Analytical Model}

This study used material flow analysis (MFA) method presented by Baccini and Brunner [8] to estimate nitrogen flow into the environment (Fig. 2). The MFA method analyzes nitrogen based on mass balance principle. The mass of all inputs into a process must equal to the mass of all outputs of the process plus a storage term that considers accumulation or depletion of material in process [9].

This study focuses on identifying the major source of nitrogen discharge and recommending methods to decrease nitrogen discharge. Analyses were performed on amounts of nitrogen input and output from major activities occurring in the Ratchaburi and Samut Songkhram provinces during the year 2010. This study selected the year 2010 as the case study because the year has the most completed secondary data. Major activities include agriculture (rice cultivation, livestock, and aquaculture), industry (agro-industry and wastewater treatment plant), household, and waste and wastewater management, in Fig. 3. A mass balance model was developed and carried out using Microsoft Excel program.

\section{Data Acquisition}

This study uses secondary and tertiary data for analysis of nitrogen flow in the basin. Data for analysis can be separated into two groups including (i) quantity of activity and (ii) concentration of nitrogen. Quantitative data such as rice cultivation areas, amounts of livestock, amounts of aquaculture, population, volume of waste, and wastewater are collected from relevant government agencies including the Department of Fisheries, Department of Livestock Development, Department of Pollution Control, and Department of Industrial Works. Concentration data are collected from available publication, mainly as follows:

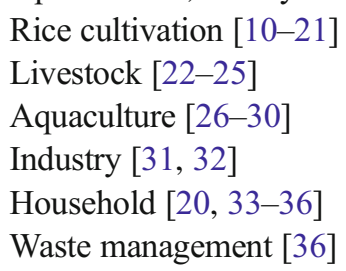

\section{Accounting Approach}

Flow in each activity is defined from the connection among various activities. The analyses performed under this model are defined based on mass balance principle along with several assumptions. For each activity, equations for estimating nitrogen flow include equations for calculating nitrogen flow and for balancing the $\mathrm{N}$ flow. To illustrate an analytical framework of the model, equations for calculating nitrogen flow for rice cultivation are presented in Tables 1 and 2 as an example. Nitrogen inputs come from activities such as irrigation, rain and fertilizer. The nutrient was absorbed by plants and changed to straw husk and rice. Some nutrient was absorbed by soil and discharged to the river. As illustrated in Fig. 2,

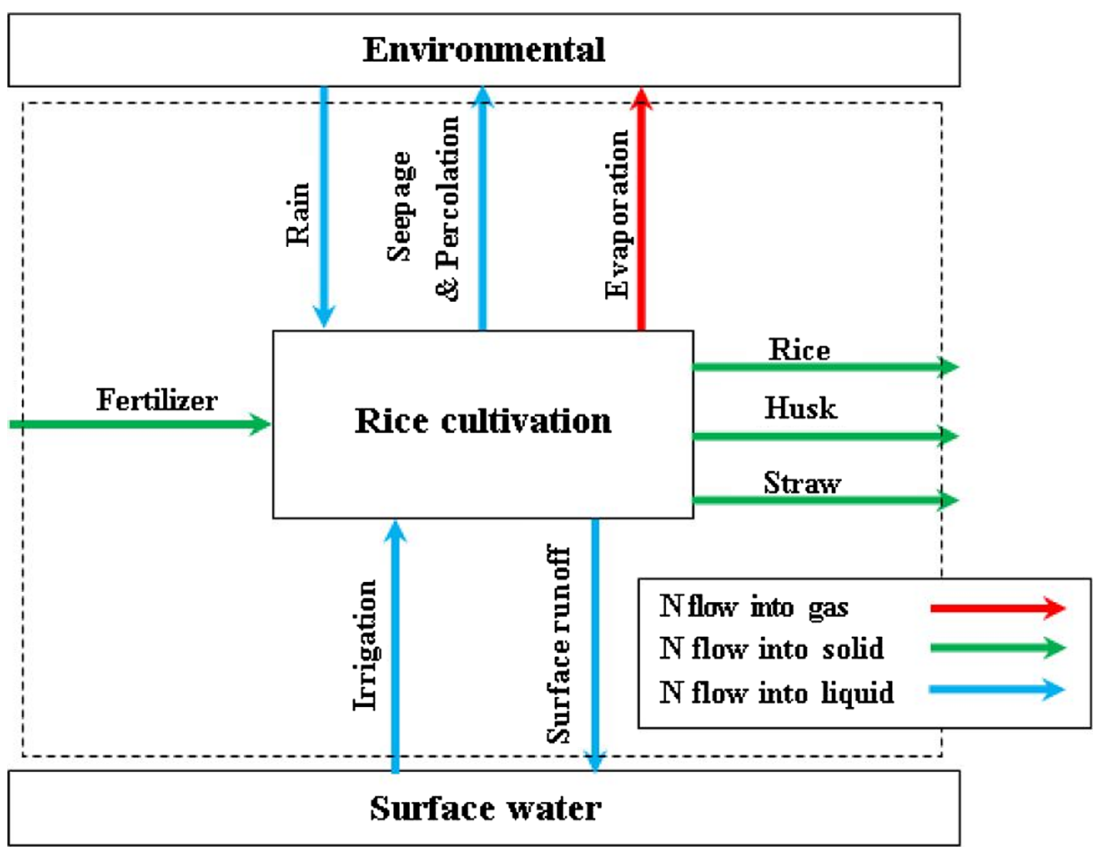

Fig. 2 Nitrogen flows in and out rice cultivation sector 


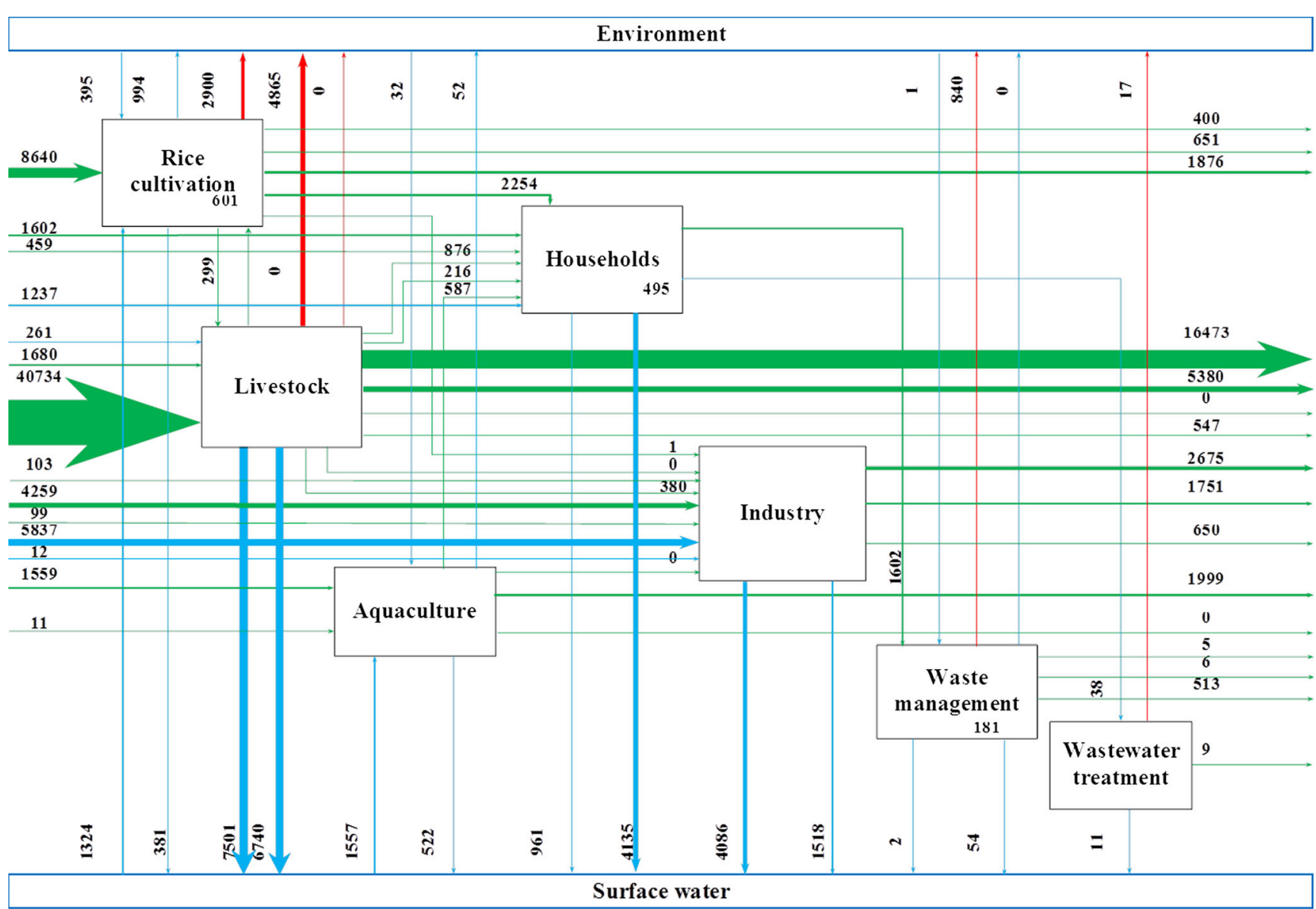

Fig. 3 Nitrogen flows through Maeklong river basin in 2010 (units are tons N/y)

flow of $\mathrm{N}$ from rice cultivation can be calculated using equations in Tables 1 and 2.

Analyses of activities in other sectors are conducted following a similar concept by accounting and balancing flows of $\mathrm{N}$ inputs and outputs from all relevant activities. Finally, flows from all activities of each sector are connected based on the relationship among inputs and outputs to balance the net $\mathrm{N}$ mass flow in the Maeklong River from the basin.

\section{Results and Discussion}

\section{Nitrogen Flow in Maeklong River Basin}

Anthropogenic nitrogen balance in the Maeklong river basin is identified as shown in Fig. 3. Nitrogen flow input and output through the river basin are approximately 69,802 and 68,516 tons $\mathrm{N}$ per year, respectively (Tables 3 and 4). The difference between $\mathrm{N}$ input and output is 1277 tons $\mathrm{N}$ per year which most probably is due to $\mathrm{N}$ storage in the system. From the input analysis, feed for livestock $(40,734 \mathrm{tN}, 58.36 \%$ of total input) and fertilizer (8640 tN, $12.38 \%$ of total input) mainly contribute to the $\mathrm{N}$ input flow compared to other activities. Excrete discharged from livestock $(16,473 \mathrm{tN}$, $24.04 \%$ of total output), wastewater (non-treatment) from livestock (7501 $\mathrm{tN}, 10.95 \%$ of total output), and wastewater (treatment) from livestock (6407 tN, $9.84 \%$ of total output) are the main output flow. The largest contributor of $\mathrm{N}$ output is from the livestock sector. Output of $\mathrm{N}$ from the river basin is in the form of solid $(53.01 \%)$, liquid $(28.32 \%)$, and gas $(18.67 \%)$. The total nitrogen flow discharge to surface water was 25,911 tons $\mathrm{N}$ per year which come from livestock and industry at approximately 54.96 and $15.96 \%$, respectively (Fig. 4). The information from the $\mathrm{N}$ flow analysis help identifying the two sectors which are the main sources of $\mathrm{N}$ discharges and need to primarily reduce $\mathrm{N}$ loads to less environmental impacts.

Livestock activities imported and exported nitrogen more than other activities (as shown in Fig.4). This is because livestock production is the main economic activities in Ratchaburi and Samut Songkram provinces. Maeklong river basin produces large amounts of livestock such as chicken, hen, beef, cow, and especially pig as compared to other nearby provinces. For reference, the numbers of animal production in the basin in 2010 were chicken $(19,780,125)$, hen $(714,677)$, duck $(645,152)$, beef $(164,124)$, cow $(58,815)$, and pig 


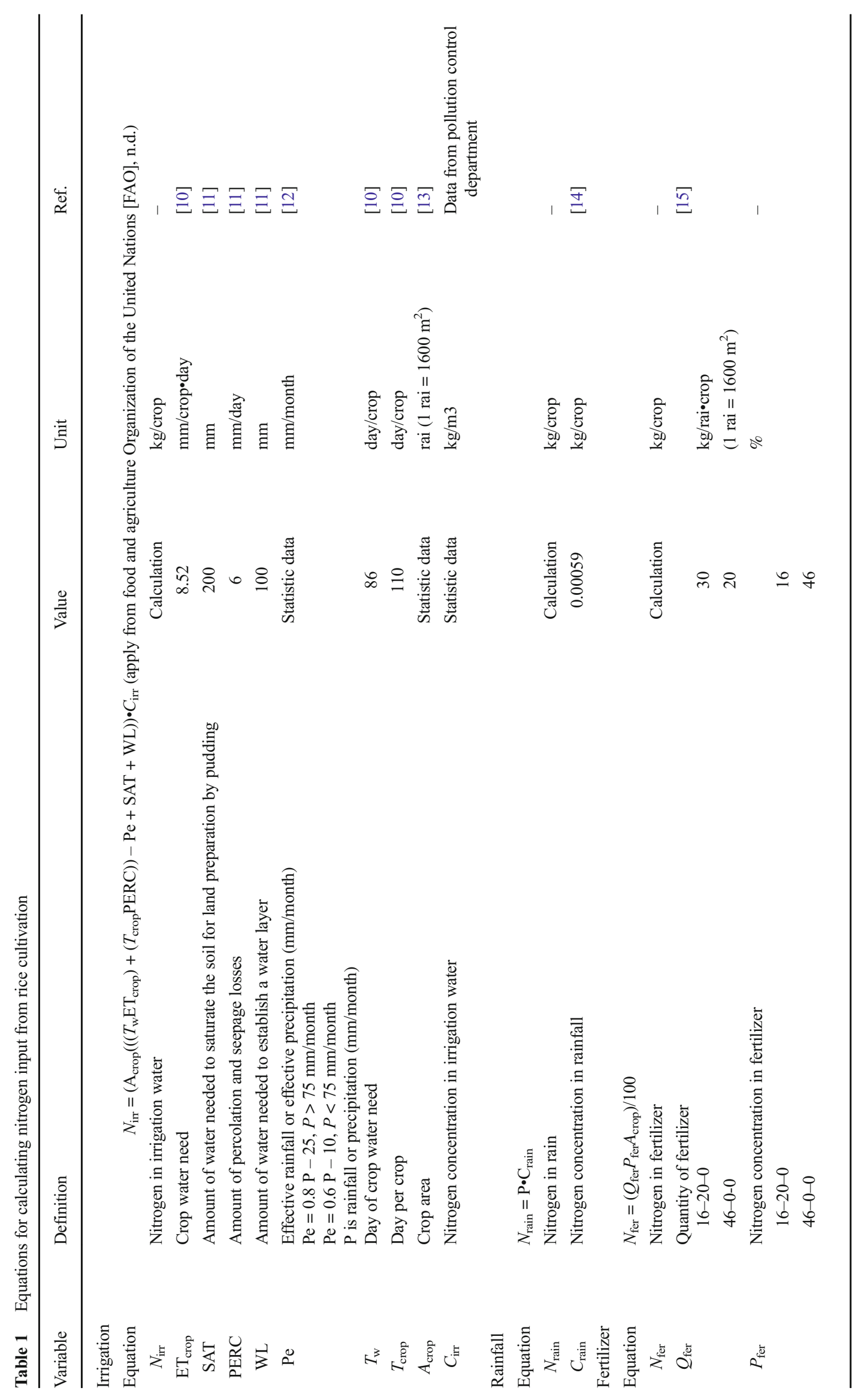


Table 2 Equations for calculating nitrogen output from rice cultivation

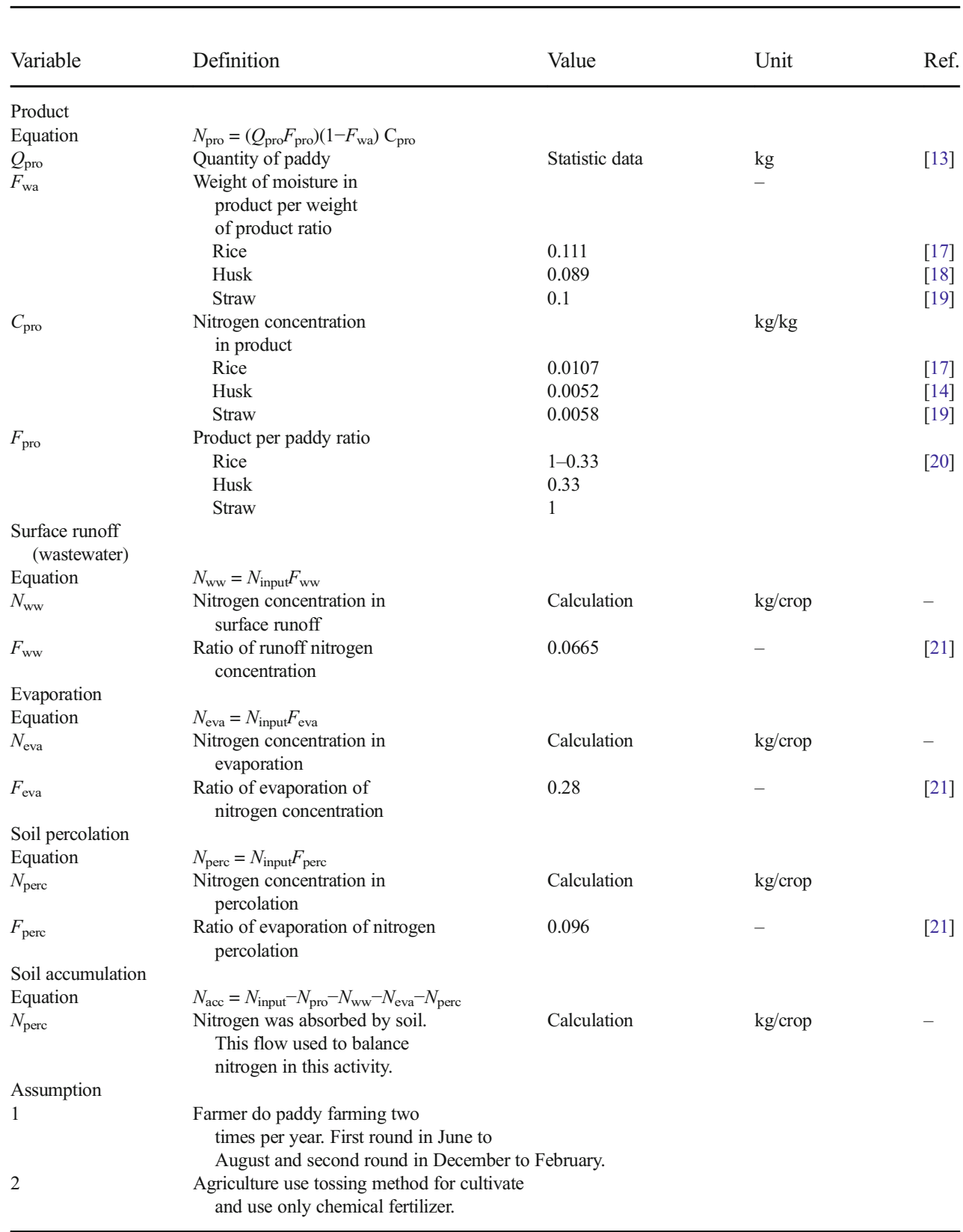

$(1,632,566)$. Food production for livestock accounted for approximately $58.36 \%$ of total nitrogen input to the basin. Nitrogen output from livestock is in the form of excretes $(16,473 \mathrm{tN})$, products $(5380 \mathrm{tN})$, gas $(4865 \mathrm{tN})$, and wastewater $(14,241 \mathrm{tN})$.

Rice cultivation mainly added $\mathrm{N}$ import from fertilizer (8640 $\mathrm{tN}, 83.41 \%$ of total input to rice cultivation) used for cultivation in two crop cycles per year, while $\mathrm{N}$ output is in the form of products (5482 tN), evaporation (2900 tN), seepage and percolation (994 tN), and surface runoff (381 tN). Aquaculture in the river basin contained various species. This activity only contributes approximately $4.53 \%$ of nitrogen to the basin. Agro-industry activity acquires and utilizes raw materials from the agricultural sector in the basin. It should be noted that if input materials are not sufficient for production, the industry will acquire materials from outside the provinces. Material input accounted for approximately 4843 tons of $\mathrm{N}$, wastewater input for approximately 5837 tons of $\mathrm{N}$ and output in the form of product for approximately 2675 tons of $\mathrm{N}(25.02 \%$ of the total $\mathrm{N}$ flow), while wastewater accounted for 5604 tons of $\mathrm{N}$ ( $52.43 \%$ of the total $\mathrm{N}$ output).

Nitrogen input and output from household activities accounted for approximately $10 \%$ of total $\mathrm{N}$ input and output from this basin. An assumption used in estimation of $\mathrm{N}$ flow from households is that $\mathrm{N}$ input to household system utilizing from $\mathrm{N}$ stock inside the basin first. If there are excess demands 
Table 3 Quantity of nitrogen input through Maeklong river basin in 2010 (units are tons N/year)

\begin{tabular}{|c|c|c|c|c|c|c|c|}
\hline Activity & Irrigation/water & Rain & Fertilizer & Material/animal & Food/feed & Waste/wastewater & Other \\
\hline Rice cultivation & 1324.45 & 394.54 & 8639.90 & - & - & - & - \\
\hline Livestock & 260.64 & - & - & 1680.49 & $41,037.08$ & - & - \\
\hline Aquaculture & 1556.52 & 31.52 & 11.20 & - & 1559.45 & - & - \\
\hline Household & 1237.30 & - & - & - & 4391.54 & - & 1601.86 \\
\hline Industry & - & - & - & 4842.64 & - & 5837.50 & - \\
\hline Waste management & - & 0.70 & - & & - & 1601.84 & - \\
\hline Wastewater treatment & - & - & - & - & - & 37.70 & - \\
\hline
\end{tabular}

Table 4 Quantity of nitrogen output through Maeklong river basin in 2010 (units are tons N/year)

\begin{tabular}{cccccccc}
\hline Activity & Seepage and percolation & Evaporation/gas & Product & Wastewater & Waste & Sedimentation/sludge & Accumulation \\
\hline Rice cultivation & 994.45 & 2900.49 & 5481.81 & 380.89 & - & 601.26 \\
Livestock & - & 4865.19 & 6852.74 & $14,241.13$ & $16,472.62$ & 546.52 & - \\
Aquaculture & 1999.00 & - & 586.60 & 521.52 & - & 1999.00 & - \\
Household & - & - & - & 5133.92 & 1601.86 & - & - \\
Industry & - & - & 2674.68 & 2176.96 & - & - & 794.92 \\
Waste management & 0.40 & 840.32 & 5.15 & 56.07 & - & -61.64 & 17.30 \\
Wastewater treatment & - & - & - & 10.91 & - & - \\
\hline
\end{tabular}

of $\mathrm{N}$ for household consumption, $\mathrm{N}$ will be imported from outside of the basin. Wastes generated from household activity were sent to municipal waste management facility and wastewater treatment plant. Waste management activity was estimated based on quantity and composition of wastes and treatment methods. The methods used for waste management included composting, combustion, open dumping, and landfill. Wastewater management facility only had a coverage area of approximately $4.06 \%$ of population in the basin. Nitrogen from household sector based on two activities accounted for approximately 2.3 and $0.05 \%$, respectively.

When comparing between input and output from major activities on nitrogen flow, livestock received major nitrogen source from foods. They were, then, converted to be an output

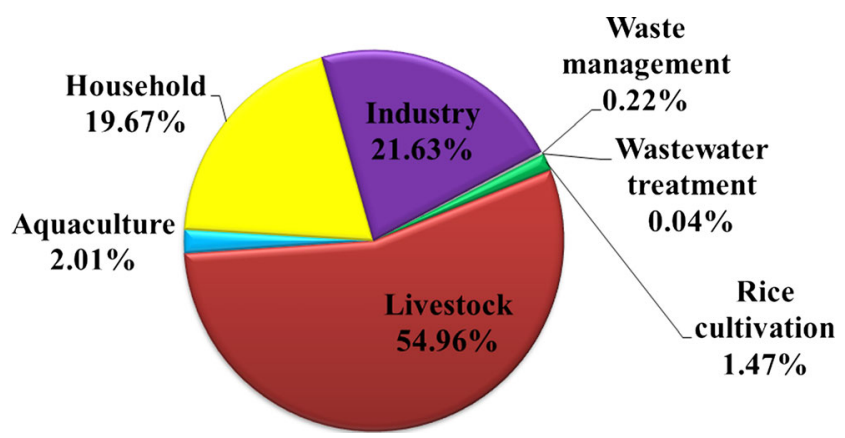

Fig. 4 Proportion of nitrogen discharging from each subsystem into surface water in four main forms including gas (ammonia), product (meat, chicken, pork, egg, milk, and other), waste (excrete), and wastewater (water discharge from activity and primary treatment). Additionally, rice cultivation had a major source of nitrogen input from fertilizer. Products (rice, husk, and straw), gas, and wastewater were nitrogen outputs from rice cultivation. Moreover, industry activities received nitrogen from raw materials and generated output as products and wastewater.

Nitrogen discharge to surface water from the activities was approximately 25,911 tons per year, with the proportion of $\mathrm{N}$ discharge as shown in Fig. 4. Livestock was the major source of $\mathrm{N}$ discharge because this basin produces large numbers of livestock and one of the assumptions for this activity is that only wastewater from pig farms was
Table 5 Ratio of nitrogen output in wastewater compare with nitrogen input to each activities

\begin{tabular}{cc}
\hline Activity & Ratio \\
\hline Rice cultivation & 0.04 \\
Livestock & 0.33 \\
Aquaculture & 0.17 \\
Household & 0.70 \\
Industry & 0.52 \\
Waste management & 0.03 \\
Wastewater treatment & 0.29 \\
\hline
\end{tabular}


treated through primary treatment. $\mathrm{N}$ discharged from the industry come from wastewater treatment plants $(72.91 \%$ of $\mathrm{N}$ discharge from industry). Since effluent from industrial sector is from point source, therefore must meet the effluent quality standards. For household activities, nearly all of $\mathrm{N}$ was discharged from septic tanks (4135 tons). Other activities had less proportion of $\mathrm{N}$ discharge. When compared between nitrogen outputs in discharge water and nitrogen inputs into activity (sector), household and industry were the major source of $\mathrm{N}$ discharge into the river (Table 5).

\section{Strategy Suggestions}

The study shows that livestock is the highest contributor of nitrogen input and output into the Meaklong River. This is mainly because of significant numbers of livestock and farms located in the area. Livestock activity supplies $\mathrm{N}$ mostly to surface water. Reducing $\mathrm{N}$ flow into the river is quite difficult through reducing the use of feeds since the production and consumption of livestock is still high. Since numbers of livestock farms in the area still do not apply appropriate wastewater treatment technology in the operation, the recommendation is to install anaerobic baffled reactor (ABR) to treat wastewater from livestock sector before discharging into the river.

To reduce nitrogen outputs into the river, the study also recommended to increase efficiency of water use and water conservation in the key sector, i.e., household and industry. This will directly related to the reduction of wastewater discharging into the river. Moreover, the coverage of wastewater collection network is still limited in the area. Therefore, wastewater treatment system is still not covered to treat wastewater from majority of households. It is recommended to improve efficiency and coverage area of wastewater collection system to bring wastewater from household to wastewater treatment plants. It will help reduce $\mathrm{N}$ and other pollutants in the river and improve water quality.

\section{Data Limitations}

Since the secondary data was used for research analysis, sources of information about activities and concentrations of nitrogen are important and need to be prioritized to ensure the accuracy of results. If some type of locally specific data is not available, the study used data and information from other existing research publication available in nearby domestic areas to estimate nitrogen flow by using acceptable assumptions and/or under similar conditions. In addition, if specific data of nitrogen concentration from certain activities was not available, information from literatures was used for the analysis.

\section{Conclusion}

The research applied the MFA model to estimate anthropogenic activities contributing to nitrogen flow into the Maeklong River from Ratchaburi and Samut Songkhram provinces in Thailand. Livestock, industry, and household are found to be the major sources of nitrogen discharge to surface water which accounted for $54.96 \%$ $(14,241 \mathrm{tN}), 21.63 \%(5604 \mathrm{tN})$, and $19.67(4135 \mathrm{tN})$, respectively. Wastewater from other activities (such as rice cultivation, aquaculture, household, waste management, and wastewater treatment) has less contribution $(3.74 \%, 969 \mathrm{tN})$. The research successfully developed an $\mathrm{N}$ flow diagram to help facilitate the $\mathrm{N}$ reduction planning process for local environmental officers with an aim to reduce risks from eutrophication. Finally, it is recommended that in order to minimize the $\mathrm{N}$ discharge in the river, wastewater from livestock farming should be treated by anaerobic baffled reactor (ABR). Reduction of wastewater from sources and improvement of wastewater collection system and treatment plants to treat wastewater from household is also important. The research findings can help increase understanding of the pollution situation and key contributors. The $\mathrm{N}$ flow diagram can help policy makers or planners to develop an effective approach to solve the problem in the future.

Acknowledgments This research is financially supported by Chulalongkorn University. The authors would like to thank Thai Governmental agencies including the Department of Industrial Works, Pollution Control Department, Department of Livestock Development, Department of Fisheries, National Statistical Office, Ministry of Resources and Environment, for providing data and suggestions for the research.

\section{References}

1. Marine Knowledge Hub (2011) Red tides (in Thai). http://www. mkh.in.th/index.php/2010-03-22-18-05-34/2010-03-26-07-59-54. Accessed 5 July 2013

2. Department of fisheries (2012) Conclusion of analyze problem of aquatics death in upper gulf of Thailand in estuaries of Maeklong river, SamutSongkhram province (in Thai). http://www.fisheries. go.th/dof/index.php?option=com_content $\&$ view $=$ article $\&$ id $=284$ \%3A2012-11-15-05-53-38\&catid=75\%3A2012-02-28-14-00-36 \&Itemid=78. Accessed 5 July 2013

3. HAII (2013) Thai Water:IGIS. Hydro and Agro Information Institute, Thailand. live1.haii.or.th/thaifloodwatch/igis/ Accessed 5 July 2013

4. Schaffner M (2007) Applying a material flow analysis model to assess river water pollution and mitigation potentials: a case study in the Thachin River Basin, Central Thailand. PhD thesis. Centre for Development and Environment (CDE) and Hydrology Group, Department of Geography, University of Bern, Bern, Switzerland.

5. Leelapanang P (2010) Material flow analysis of nitrogen through food production and consumption for watershed management in Chaophraya River Delta, Thailand. PhD thesis, Department of 
Urban Engineering, Graduate School of Engineering, The University of Tokyo, Tokyo, Japan

6. Finnveden G, Moberg A (2005) Environmental systems analysis tools - an overview. J Clean Prod 13:1165-1173

7. Office of Agricultural Economic (2011) Agriculture statistics of Thailand 2011. Office of Agricultural Economic, Bangkok

8. Baccini P, Brunner PH (2012) Metabolism of the anthroposphere: analysis, evaluation, design. The MIT Press, Cambridge

9. Brunner PH, Rechberger H (2004) Practical handbook of material flow analysis. Lewis, CRC Press LLC, Boca Raton, Florida

10. Wongsutisaroj $\mathrm{S}$ (n.d.) Water consumption of rice(in Thai). http://www.rid.go.th/attatch_branch/qrice.html. Accessed 01 September 2013

11. Food and Agriculture Organization of the Uniteds Nations (n.d.) IRRIGATION WATER NEEDS. http://www.fao.org/docrep/s2022 e/s2022e08.htm. Accessed 16 April 2013

12. National Statistical Office (n.d.) Volume of precipitation per month 2009-2010 (in Thai). http://samutsongkhram.nso.go. th/nso/project/table/files/smskhram/O-src-23/2549/000/smskhram_Osrc23_2549_000_40000300.xls. Accessed 01 September 2013

13. Office of Agricultural Economics (2012) Agricultural statistics of Thailand 2011(in Thai). http://www.oae.go.th/download/download journal/yearbook54.pdf. Accessed 01 Febuary 2013

14. Paramee S, Chidthaisong A, Towprayoon S, et al. (2015) Threeyear Moniroring results of nitrate and ammonium wet deposition in Thailand. Environ Monit Assess 102:27-40

15. Prenthaisong $P$ (n.d.) Rice cultivation by toss method. (in Thai) http://wqm.pcd.go.th/km/images/stories/agriculture/2555 /throwingrice.pdf. Accessed 01 June 2013

16. Gadde B, Menke C, Wassmann R (2009) Rice straw as a renewable energy source in India, Thailand, and the Philippines: overall potential and limitations for energy contribution and greenhouse gas mitigation. Biomass Bioenergy 33:1532-1546 Rice

17. Department of Thailand (n.d.) utilization husk and other product (in Thai). http://www.riceproduct.org/index.php?option=com content\&task=view\&id=94\&Itemid=50 Accessed 01 June 2013

18. Heinemann RJB, Fagundes PL, Pinto EA, et al. (2005) Comparative study of nutrient composition of commercial brown, parboiled and milled rice from Brazil. J Food Compos Anal 18: 287-296

19. Lim JS, Manan ZA, Alwi SRW, Hasin H (2012) A review on utilisation of biomass from rice industry as a source of renewable energy. Renewable and Sustainable Reviews 16:3084-3094

20. Liang XQ, Chen YX, Li H, et al. (2007) Modeling transport and fate of nitrogen from urea applied to a near-trench paddy field. Environ Pollut 150:313-320

21. Food and Agriculture Organization of the United Nations (n.d.) Livestock sector brief Thailand. http://www.fao. org/ag/againfo/resources/en/publications/sector_briefs/lsb_THA.pdf. Accessed 01 September 2013
22. Misselbrook TH, Van Der Weerded TJ, Pain BF, et al. (2000) Ammonia emission factors for UK agriculture. Atmos Environ 34:871-880

23. Smith KA, Charles DR, Moorhouse D (2000) Nitrogen excretion by farm livestock with respect to land spreading requirements and controlling nitrogen losses to ground and surface water. Part 2: pigs and poultry. Bioresour Technol 71:183-194

24. Smith KA, Frost JP (2000) Nitrogen excretion by farm livestock with respect to land spreading requirements and controlling nitrogen losses to ground and surface water. Part 1: cattle and sheep. Bioresour Technol 71:173-181

25. Casillas-Hernandez R, Magallon-Barajas F, Portillo-Clarck G, Paez-Osuna F (2006) Nutrient mass balances in semi-intensive shrimp ponds from Sonora, Mexico using two feeding strategies: trays and mechanical dispersal. Aquaculture 258:289-298

26. Jackson C, Preston N, Thompson PJ, Burford M (2003) Nitrogen budget and effluent nitrogen components at an intensive shrimp farm. Aquaculture 218:397-411

27. Paez-osuna F, Guerrero-galvan SR, Ruiz-fernandez AC, Espinozaangulo R (1997) Fluxes and mass balances of nutrients in a semiintensive shrimp farm in north-western Mexico. Mar Pollut Bull 34: 290-297

28. Saeuy U (2008) Flow of nitrogen in the Snakeskin Gourami (Trichogaster pectoralis Regan) Raising Pond using material flow analysis at Samut Songkhram Province. Master's Thesis, Faculty of Graduate Studies Mahidol University, Thailand

29. Tarkul PD, Lin CK (2003) Water quality and nutrient budget in closed shrimp (Penaeus monodon) culture system. Aquac Eng 27: 159-176

30. Diego-mcglone MLS, Smith SV, Nicolas VF (2000) Stoichiometric interpretations of C:P:N ratios in organic waste materials. Mar Pollut Bull 40:325-330

31. Nowvabut, T (2013) (Assessment water use of domestic and industrial.). http://202.129.59.73/wm/ Water/water\%20demand\%201.pdf. Accessed 5 July 2013

32. Food and Agriculture Organization of the United Nations (n.d.) Food composition tables for international use. http://www.fao. org/docrep/X5557e/x5557e00.htm\#Contents. Accessed 17 September 2013

33. Food and Agriculture Organization of the United Nations (n.d.) National fishery sector overview Thailand. http://ftp.fao. org/Fi/DOCUMENT/fcp/en/F1 CP TH.pdf. Accessed 01 September 2013

34. Gerbens-Leenes PW, Nonhebel S, Krol MS (2010) Food consumption patterns and economic growth. Increasing affluence and the use of natural resource. Appetite 55:597-608

35. Kennedy G, Burlingame B, Nguyen VN (n.d.) Nutritional contribution of rice and impact of biotechnology and biodiversity in riceconsuming countries. http://www.fao.org/docrep/006/y4751 e/y4751e05.htm. Accessed 01 September 2013

36. Pichtel J (2005) Waste management practices: municipal, hazardous, and industrial, 2 ed. CRC press, Florida 